\title{
Revista on line de Política e Gestão Educacional
}

v.21, n.3, set./dez. 2017

\section{Editorial}

A Universidade Produtivista e o Produtivismo Acadêmico: a quem serve?

Há dias que procuro compreender um assunto que tenho chamado de "trama do produtivismo" na academia e porque este se tornou a principal incógnita da equação que sustenta o "publicar ou perecer". Em alguns momentos me parece tão óbvio, e no momento seguinte, me encontro buscando argumentos e respostas que me convençam do contrário. Porque abandonamos o princípio da autonomia universitária "conquistada" com suas prerrogativas para a produção do conhecimento? Não estaríamos também, nesse contexto, sendo obrigados a priorizar a produção acadêmica - na forma de publicação - de textos em detrimento de outras funções, tão ou mais importantes, que exercemos no cotidiano de formação do segmento qualificado (escolarizado) na sociedade? Os órgãos públicos de fomento, sem nenhuma dúvida, são de grande importância na produção da pesquisa em qualquer lugar do mundo, contudo, parecem estar nesse momento ${ }^{1}$ substituindo a responsabilidade que cabe, de fato, com relação às Instituições Públicas. A métrica determinante da "eficiência" não mais é dada pelos pares ou mesmo pela sociedade, mas por grupos com suas publicações qualificadas que “representam” e "espelham” a qualidade da área e seus conteúdos.

O editor executivo para humanidades na Harvard University Press, Lindsay Waters, nos provoca, com raro brilhantismo e sensibilidade, ao publicar seu ensaio intitulado "Inimigos da Esperança. Publicar, perecer e o eclipse da erudição”. Neste, sugere que a comercialização da educação superior chegou a cada departamento de

${ }^{1}$ Considerando o produtivismo uma espécie de movimento internacional que avança sobre as Instituições Públicas Universitárias na maioria dos países, cf. mostra o texto A Universidade Produtivista se globaliza (e, portanto, é a sua resistência); Willem Halffman and Hans Radder. (Tradução deste autor) 
humanidades em cada universidade. Dessa forma, se apropria de elementos essenciais ao cerne do processo: a publicação.

Tais considerações reflexivas sobre o sentido e significado das publicações acadêmicas nos impõe indagações pertinentes relativas à nossa posição como produtores desses conhecimentos. Entre essas inúmeras indagações que me inquietam está a que vem de uma situação de grande dubiedade, uma vez que há um certo consenso na literatura e no cotidiano acadêmico de que o produtivismo - e a universidade produtivista - é nociva à produção qualificada da instituição, e que a competitividade gerada entre os pares favorece certa animosidade nas relações. Contudo e apesar disso, em outro sentido, a busca pelo produtivismo é uma realidade clara no cotidiano acadêmico por parte dos pesquisadores e gestores universitários (policy makers).

A instituição normatiza e regulamenta parâmetros com métricas estabelecidas por organismos alheios e distantes delas, cujos interesses, princípios e objetivos parecem, salvo melhor juízo, incongruentes com a realidade universitária ou acadêmica para produção do conhecimento. Não se tem acordo sobre os critérios, conceitos ou fundamentos efetivos para a construção de instrumentos adequados, e por isso empregase critérios e parâmetros abstraídos de modelos, se não anacrônicos, inadequados e, em geral, sem fidedignidade ao objeto e à circunstância na qual se encontra. Colocar esses embates acadêmicos com suas contradições à mostra e na direção do consenso exige tempo e condições para um trabalho complexo, por vezes insuficientes. O tempo, em geral desconsiderado para determinação dessas métricas, é um bem cada vez mais escasso na Universidade, e as condições adequadas para o trabalho se reduzem a cada momento. Nesse sentido e contexto, a cada dia temos que produzir mais, escrever mais, publicar mais, para uma sociedade, organismos ou pares que leem cada vez menos e, quando leem, a qualidade do conteúdo não é o que importa. O que importa é a métrica do quanto foi escrito e onde está publicado.

Vivemos hoje um momento em que nossos pares deliberadamente entregaram suas opiniões sobre o que pesquisamos e escrevemos aos terceirizados, aqueles que se esmeram em construir exigências para divulgarem nossos estudos como se dependesse deles a qualidades dos resultados. Como pode, nesse contexto, a universidade auxiliar o país a refletir e a encontrar caminhos com sua subserviência a órgãos de fomento que lhes subtraem autonomia e prescrevem objetivos, ações e metas no sentido gerencial do termo? Willem Halffman e Hans Radder nos esclarecem, mas também nos desconfortam ainda mais, ao afirmar que há administradores que acreditam que não há 
alternativas para a academia, uma vez que é assim que as universidades deveriam ser: gerenciadas profissionalmente. Entendem que o modelo deve se espalhar por países com "necessidade de modernização - como aspirantes a candidatos da UE - ou retardatários globais". (SERRC, July 13, 2017). Algo aqui me remete novamente à Lindsay Waters, ao analisar a perda da qualidade da produção literária acadêmica. As publicações estão efetivamente postas para as humanidades como o que lhe é mais caro e, se não temos claro o que significa a troca do conteúdo qualificado da publicação pelo número que representa entre as nossas publicações no período, então posso, pelo menos inferir, como Waters, que possa haver "uma relação causal entre a demanda corporativa pelo aumento da produtividade e o esvaziamento, em todas as publicações, de qualquer significação que não seja gerar números.” Temos aceitado uma visão contábil auditorial que produz efeito ilusório com fim em si mesmo.

Por essa ótica, cuja universidade e sua produção são vistas por meio de filtros contábeis, se nossos textos deixam de ser os registros complexos que compõem, entre outros, parte significativa de nossos objetos de estudos para conhecermos e produzirmos conhecimentos, mas passam a ser geradores de números que cumprem determinado papel na produtividade acadêmica, nós, e as humanidades em geral, estamos com um imenso problema a ser resolvido. Nesse contexto se estabelece algo paradoxal: A quem servimos? A sociedade e ao conhecimento ou a grupos de interesses particulares?

Os Editores

Sebastião de Souza Lemes e Ricardo Ribeiro 